\title{
Genetic structure of eelgrass Zostera marina meadows in an embayment with restricted water flow
}

\author{
Raquel Muñiz-Salazar ${ }^{1, *}$, Sandra L. Talbot ${ }^{2}$, George K. Sage ${ }^{2}$, David H. Ward ${ }^{2}$, \\ Alejandro Cabello-Pasini ${ }^{1}$
}

${ }^{1}$ Instituto de Investigaciones Oceanológicas, Universidad Autónoma de Baja California AP 453, Ensenada, Baja California 22800, Mexico

${ }^{2}$ Alaska Science Center, US Geological Survey, 1011 E. Tudor Road, Anchorage, Alaska 99503, USA

\begin{abstract}
Genetic structure of the seagrass Zostera marina in a coastal lagoon with restricted water flow, and with heterogeneous water residence times and oceanographic characteristics, was assessed using 8 polymorphic microsatellite loci. Analyses of genetic differentiation $(\theta)$ and Bayesian clustering suggested that the Z. marina population in San Quintin Bay (SQB) is genetically substructured, with at least 4 genetically different groups: (1) West Head, (2) Mouth, (3) East Arm, and (4) East Head. The greatest $\theta$ value was observed between the most distant sites $(\theta=0.095)$. The lowest values were found among sites closest to the mouth of the coastal lagoon $(\theta=0.000$ to 0.009$)$. The maximum likelihood approach showed that the sites at the mouth have a mixed pattern of gene flow without a unidirectional pattern. In contrast, there was a clear pattern of asymmetrical gene flow from the mouth towards the West Head. These results suggested that the restriction of water flow at the heads, current pattern, and the distance between sites can reduce genetic flow and promote genetic differences within $Z$. marina meadows in small water embayments such as SQB. Though the population is genetically substructured and a $14 \%$ decline in cover has been detected, this study did not show evidence of a recent genetic bottleneck. In contrast, mouth sites have experienced a recent expansion in their population size, and also perhaps a recent influx of rare alleles from genetically distinct immigrants.
\end{abstract}

KEY WORDS: Small structure - Microsatellites - Zostera marina - San Quintin Bay · Bottleneck · Barriers Resale or republication not permitted without written consent of the publisher

\section{INTRODUCTION}

Marine populations can be genetically structured as a result of oceanographic (i.e. channels, peninsulas, currents, bathymetry), ecological (temperature, salinity, light, nutrients) or human-made barriers (e.g. dams, roads, hydro accesses, urban areas, aquacultural areas) (Hedgecock 1986, Avise 1994, Muñiz-Salazar et al. 2005). The presence of these barriers decreases the dispersal, migratory, and reproductive capabilities of individuals and leads to the restriction of gene flow and formation of genetically isolated groups (Slatkin 1987). Although genetic structure has been demonstrated at macrogeographic scales in several seagrass populations (Procaccini \& Mazella 1998, Reusch et al.
1999, Olsen et al. 2004, Muñiz-Salazar et al. 2005), there are few studies that demonstrate whether microgeographic genetic isolation occurs (Ruckelshaus 1998, Procaccini et al. 1999, Reusch 2002, Billingham et al. 2003, Ruggiero et al. 2005). Estuaries and coastal lagoons are heterogeneous habitats where physical, chemical, and ecological factors interact with complex dynamics creating spatially discrete and fragmented habitats for most species inhabiting these embayments (Bilton et al. 2002). These factors have been shown to create eco-physiological and oceanographic barriers in large estuaries, which can promote genetic differentiation in a range of taxa including the seagrass Zostera marina (Ruckelshaus 1998, Williams \& Orth 1998), the seaweed Alaria marginata (Kusumo \& Druehl 2000) 
and the salt marsh grass Elymus athericus (Bockelmann et al. 2003).

San Quintin Bay (SQB) is a Y-shaped coastal lagoon located at the northern end of the peninsula of Baja California. It is a small $\left(42 \mathrm{~km}^{2}\right)$ but heterogeneous habitat characterized by a clear nutrient, salinity, and temperature gradient from the mouth to the 2 heads of the lagoon (Hernandez-Ayón et al. 2004). This coastal lagoon has an average depth of $2 \mathrm{~m}$ and extensive intertidal and shallow subtidal flats. Narrow tidal channels extend along the length of both arms and are strongly differentiated from the shallow bay flats by changes in depth. In general, the channels have depths of 5 to $7 \mathrm{~m}$ (Álvarez-Borrego 2004). As a consequence of low incident irradiance and high water turbidity, Zostera marina meadows occur mainly in the intertidal zone (Cabello-Pasini et al. 2003, 2004). Tides are predominantly semidiurnal and are the main factor influencing water circulation (Martori-Oxamendi 1989). Current velocities of up to $100 \mathrm{~cm} \mathrm{~s}^{-1}$ occur in the region near the mouth, decreasing toward the inner reaches to maximum velocities of $\sim 60 \mathrm{~cm} \mathrm{~s}^{-1}$ (Ocampo-Torres 1980, Martori-Oxamendi 1989). Furthermore, water flow at the East Head of the lagoon is restricted to an approximately $10 \mathrm{~m}$ wide channel because of construction of a dike at the beginning of the 20th century. The dike helped to direct and restrict water flow to a tidally-moved flour mill wheel. It is not known, however, if the different oceanographic conditions, such as current patterns and sharp temperature and salinity gradients, have created barriers to slow down the dispersion of propagules and consequently to restrict gene flow of $Z$. marina at SQB.

The seagrass Zostera marina is the dominant submerged macrophyte of coastal embayments along the peninsula of Baja California (Mexico). At SQB, Z. marina covers approximately $43 \%$ of the total area of the lagoon (Cabello-Pasini et al. 2003, Ward et al. 2004a,b). Perennial meadows of $Z$. marina at SQB reproduce both vegetatively by rhizome elongation, and sexually through hydrophilic pollination (Poumián-Tapia \& Ibarra-Obando 1999, Meling-López 2001, Cabello-Pasini et al. 2003). The density of flowering shoots shows a clear seasonal pattern with maximum densities from June to July. During these months, flowering shoots represent approximately $45 \%$ of total shoot density (Cabello-Pasini et al. 2003). In general, the dispersal of pollen and seeds is influenced by water currents that promote stochastic and restricted dispersion (De Cock 1980, Ackerman 1997). Furthermore, detached seeds remain buried in the sediment near the mother plant in a latent stage, suggesting a low level of sexual recruitment (Orth et al. 1994, Ruggiero et al. 2005). Thus, it would be expected that the restricted dispersal potential of pollen and seeds of $Z$. marina and the presence of oceanographic barriers in a small spatial scale would lead to significant genetic structure in small embayments, such as SQB.

Industries such as aquaculture are currently operating in SQB at a sustainable rate (Aguirre-Muñoz et al. 2001, Correa et al. 2004, García-Esquivel et al. 2004); however, the cover of Zostera marina meadows has declined by $14 \%$ (mainly in subtidal zones) over the last 2 decades (Ward et al. 2004a,b). This habitat fragmentation reduces the size and increases the spatial isolation of plant populations, and decreases the effective population size thus leading to bottlenecks. Identification of recently bottlenecked populations is important because it could increase demographic stochasticity and rate of inbreeding, loss of genetic variation, decline of gene flow, and fixation of deleterious alleles, thereby reducing the adaptive potential and increasing the probability of population extinction (Young \& Clarke 2000). Some studies that used direct methods to investigate bottlenecks in animal and plant species did not detect a reduction in census size, even though they showed a severe reduction in effective population size (Ne: genetic bottleneck) when these organisms were analyzed using genetic methods (Cornuet \& Luikart 1996, Luikart \& Cornuet 1998). Thus, it is critical to evaluate whether the reduction in $Z$. marina meadows in SQB has affected the genetic diversity of the population, and whether the differing water residence times, current patterns, environmental parameters, and anthropogenic activities have also promoted the genetic isolation of the $Z$. marina population at different sites. Consequently, the objectives of this study were: (1) to determine if there is genetic substructuring in $Z$. marina populations in a small embayment with different water residence times and oceanographic conditions, and (2) to assess if the reported decrease in meadow cover has resulted in a reduction in genetic diversity of $Z$. marina at SQB.

\section{MATERIALS AND METHODS}

Study sites. Zostera marina shoots from 7 sites throughout SQB were sampled during winter 2000 and spring 2002 (Fig. 1). The sampling sites were: West Head (A), West Arm (B), Monte Ceniza (C), Mouth (D), Pedregal (E) Molino Viejo (F), and East Head (G). Between 16 and 26 individuals, separated by 20 to $100 \mathrm{~m}$, were collected manually from each site during low tide or by skin-diving during high tide. The area over which sampling was carried out ranged from 0.4 to $0.8 \mathrm{~km}^{2}$, depending on the size of the $Z$. marina meadow (Fig. 1). The position of each shoot collected was determined using GPS. Individuals were cleaned 


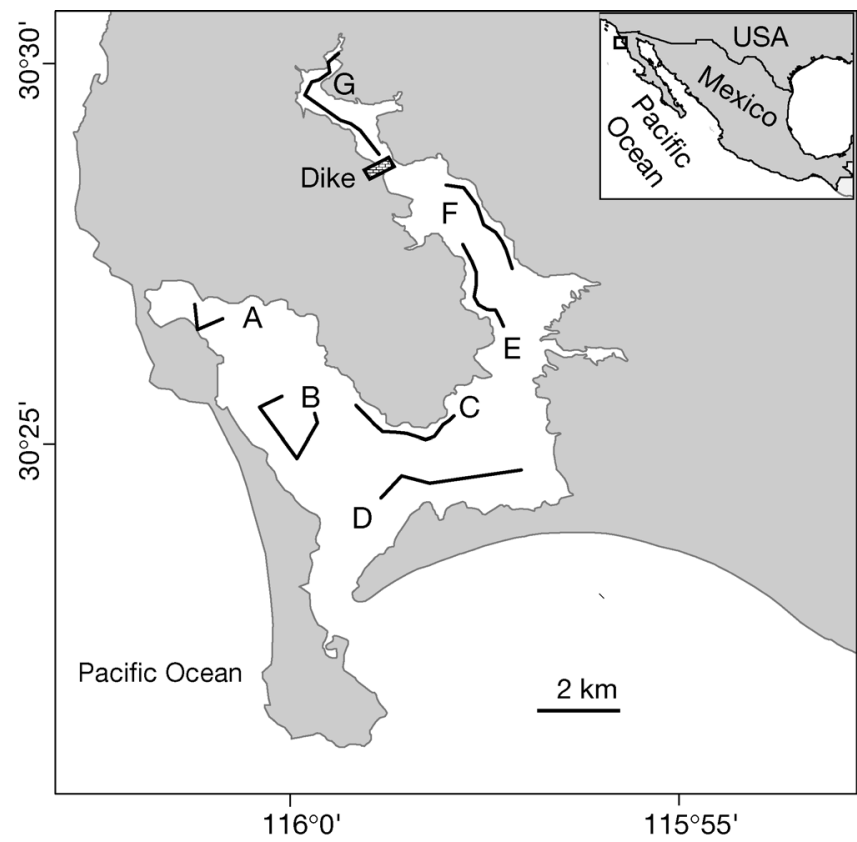

Fig. 1. Zostera marina. Location of 7 sampling sites in San Quintin Bay (SQB). A, West Head; B, West Arm; C, Monte Ceniza; D, Mouth; E, Pedregal; F, Molino Viejo; G, East Head

of epiphytes, blotted dry with paper towels, and stored in silica gel until DNA was extracted from leaf tissue.

Microsatellite analysis. Genomic DNA was extracted from approximately 0.02 to $0.04 \mathrm{~g}$ (dry weight) of leaf tissue using the CTAB/PVP (hexadecyl trimethyl ammonium bromide/polyvinyl pyrrolidone) protocol described by Muñiz-Salazar et al. (2005). DNA samples were genotyped using 8 microsatellite loci described by Reusch et al. (1999, 2000). Loci used included Zosmar (CT-3, CT-19, CT-20, GA-1, GA-2, GA-3, GA-4, GA-5). Microsatellite regions were amplified and visualized as described by Muñiz-Salazar et al. (2005).

Data analysis. Genetic diversity: Sites were treated as populations during the analysis. Simpson's measure of diversity ( $D$ : [Simpson 1949], corrected for finite sample size [Pielou 1969]), was used to assess clonality in the populations. Simpson's measure evaluates the probability of detecting any 2 individuals drawn at random from a finite community of possible genotypes: $D=1-\Sigma\left[\mathrm{n}_{i}\left(\mathrm{n}_{i}-1\right) \times \mathrm{N}(\mathrm{N}-1)^{-1}\right]$, where $\mathrm{n}_{i}$ is the number of individuals of multilocus genotype $i$ and $\mathrm{N}$ is the total number of individuals sampled. The $D$ value ranges from 0 (when the population is composed of 1 genet) to 1 (when every ramet is a different genet). Any pair of individuals sharing identical multilocus genotypes (clones) was dropped from further analysis. The probability of observing identical multilocus genotypes between 2 individuals sampled from a population (Pi) was also evaluated using GIMLET 1.3.2 (Valieré 2002).
The numbers of alleles and heterozygosities (observed and expected) for each locus across all populations were calculated using GDA 1.0 (P. Lewis \& D. Zaykin unpubl. $)^{\mathbf{1}}$. Allelic richness per locus and population was calculated using FSTAT 2.9.3 (J. Goudet unpubl.) ${ }^{2}$. Global deviation from Hardy-Weinberg equilibrium (HWE) to assess heterozygote deficit was tested using a Markov chain algorithm developed by Guo \& Thompson (1992), and linkage disequilibrium between all pairs of loci was estimated using GENEPOP 3.1d (Raymond \& Rousset 1995). In all cases of multiple tests, significance levels were adjusted using sequential Bonferroni corrections (Rice 1989). The p value was calculated by dividing the significance level (0.05) by the number of loci (8) ( $p=0.006)$.

Population substructure: Population substructure of Zostera marina was studied using 2 methods. (1) Genetic pairwise differentiation among the 7 predefined populations according to geographical localization was quantified using estimators of $F_{\mathrm{ST}}$ (Weir \& Cockerham 1984) by Arlequin 1.1 (S. Schneider et al. unpubl.) $)^{3}$. Statistical significance of the variance measurements was tested with non-parametric permutations. (2) The population structure was tested by the Bayesian clustering method developed by Pritchard et al. (2000) and implemented in STRUCTURE 1.0. This analysis assumed that there were $K$ ( $K$ may be unknown) subpopulations (sites) pooled into a hypothetical single population, each of which is characterized by a set of allele frequencies at each locus. Individuals in the sample were assigned probabilistically to subpopulations, or jointly to 2 or more subpopulations if their genotypes indicated that they were admixed. In this study the a posteriori probabilities of $K$ (i.e. the likelihood of $K$ as a proportion of the sum of likelihoods for different values of $K$ ) were estimated assuming uniform prior values on $K$ between 1 and 7 (corresponding to each site sampled, A to $G$ ). The proportion of membership $(q)$ of individuals in sites or group of sites identified by clustering was also estimated with STRUCTURE 1.0. The results were based on runs of 100000 iterations following a burn-in-period of 10000 iterations. Isolation by distance was analyzed by regression pairwise estimates of $\theta(1-\theta)^{-1}$ against log-distance between sites (Rousset 1997).

Migration: The magnitude and polarity of gene flow among sites in SQB was evaluated using the maximum

\footnotetext{
${ }^{1}$ Genetic data analysis: computer program for the analysis of allelic data; available at http://hydrodictyon.eeb.uconn.edu/ people/plewis/software.php

${ }^{2}$ FSTAT: a program to estimate and test gene diversities and fixation indices; available at www2.unil.ch/popgen/ softwares/fstat.htm

${ }^{3}$ ARLEQUIN: A software for population genetic data; available at http://lgb.unige.ch/arlequin/
} 
likelihood approach implemented in MIGRATE 1.7.6 (Beerli \& Felsenstein 1999). MIGRATE uses a coalescence approach to estimate migration rates $(\mathrm{Nm})$ among populations, assuming a constant per-locus mutation rate $(\mu)$. This approach is judged to estimate gene flow more accurately than other $F_{\mathrm{ST}}$ methods, especially when multiple loci are employed (Beerli \& Felsenstein 1999). Ten short-chain searches and 3 long-chain searches over 9 microsatellite loci were used. The program assumes discrete populations and generations, mutation-drift equilibrium, no selective effects and the Stepwise Mutation Model (SMM; Ohta \& Kimura 1973) for microsatellite markers.

Bottleneck test: The program BOTTLENECK 1.1 (Piry et al. 1997) was employed to test whether the level of heterozygosity derived from the observed allele frequencies per site differed from the heterozygosity expected under mutation-drift equilibrium. The heterozygosity excess test can be used to assess whether genetic diversity within populations has been reduced by changes in the cover of Zostera marina meadows throughout SQB. The Wilcoxon sign-rank test was used to determine whether a population exhibited a significant number of loci with heterozygosity excess. Since this test provides relatively high power it can be used with as few as 4 polymorphic loci and any number of individuals (Luikart et al. 1998a). The extent and significance depend on the model of mutation used to analyze the microsatellite loci studied (Cornuet \& Luikart 1996). Because the mutation model for most microsatellite loci is probably intermediate between the Infinite Allele Model (IAM; Kimura \& Crow 1964) and the SMM (Ohta \& Kimura 1973), both models plus the Two Phase Model (TPM; Di Rienzo et al. 1994) were used for this analysis. The TPM is intermediate between the strict (1-step) SMM and the IAM (Luikart et al. 1998b). Parameters for the TPM were set at $88 \%$ single step mutations, with a variance of 9 (Piry et al. 1997, Garza \& Williamson 2001).

\section{RESULTS}

\section{Genetic diversity}

The total number of alleles detected per locus ranged from 3 (CT-19) to 19 (CT-20) (data not shown), and the mean number of alleles per locus and population (observed allelic diversity) ranged from 4.5 (Site F) to 6.4 (Site D) (Table 1). We observed no clones in any population $(D=1.0)$. Probability of identity $(P i)$ values for each multilocus genotype ranged from $5.29 \times 10^{-6}$ to $9.55 \times 10^{-5}$. Allelic richness varied from 4.1 (Site F) to 5.4 (Site B). Private alleles were found in all populations except at Site F. The greatest number (6) of pri-
Table 1. Zostera marina. Measures of population diversity and estimates of Hardy-Weinberg equilibrium (HWE) in San Quintin Bay (SQB). A, West Head; B, West Arm; C, Monte Ceniza; D, Mouth; E, Pedregal; F, Molino Viejo; G, East Head. $\mathrm{AL}$, mean number of alleles; AR, allelic richness; PA, number of private alleles; $H_{\mathrm{O}}$, observed heterozygosity; $H_{\mathrm{E}}$, expected heterozygosity (Nei 1987); ${ }^{*}$ significance at $\mathrm{p}<0.005$ (Bonferroni correction applied); ns, not significant

\begin{tabular}{|lccccccc|}
\hline Site & $\mathrm{n}$ & $\mathrm{AL}$ & $\mathrm{AR}$ & $\mathrm{PA}$ & $H_{\mathrm{E}}$ & $H_{\mathrm{O}}$ & $\mathrm{HWE}$ \\
\hline $\begin{array}{l}\text { SQB } \\
\text { (all sites) }\end{array}$ & 146 & 9.3 & 9.3 & - & 0.554 & 0.521 & $*$ \\
$\mathrm{~A}$ & 19 & 4.9 & 4.5 & 2 & 0.555 & 0.533 & $\mathrm{~ns}$ \\
$\mathrm{~B}$ & 16 & 5.5 & 5.4 & 4 & 0.563 & 0.526 & $\mathrm{~ns}$ \\
$\mathrm{C}$ & 19 & 5.6 & 5.2 & 1 & 0.549 & 0.518 & $\mathrm{~ns}$ \\
$\mathrm{D}$ & 26 & 6.4 & 5.3 & 3 & 0.548 & 0.547 & $\mathrm{~ns}$ \\
$\mathrm{E}$ & 18 & 4.8 & 4.5 & 2 & 0.523 & 0.519 & $\mathrm{~ns}$ \\
$\mathrm{~F}$ & 20 & 4.5 & 4.1 & 0 & 0.491 & 0.473 & $\mathrm{~ns}$ \\
G & 25 & 5.6 & 4.7 & 6 & 0.540 & 0.528 & $\mathrm{~ns}$ \\
Average & 18 & 5.3 & 4.8 & 2.6 & 0.539 & 0.520 & $\mathrm{~ns}$ \\
& & & & & & & \\
\hline
\end{tabular}

vate alleles was found at Site G. No clones were observed $(P d=0)$ at any of the sites studied. Average expected heterozygosities $\left(H_{\mathrm{E}}\right)$ ranged from 0.491 at Site F to 0.563 at Site B, and average observed heterozygosities $\left(H_{\mathrm{O}}\right)$ ranged from 0.473 at Site $\mathrm{F}$ to 0.547 at Site D (Table 1). Of the 8 loci analyzed, none were out of HWE across sites $(p>0.006)$. When all sites were pooled, the global test revealed significant departures $(p<0.006)$ from HWE due to significant heterozygote deficit in 3 loci (CT-20, GA-1, and GA-3). However, when sites were analyzed as separate populations according to geographical distribution, the global test revealed no significant departures from HWE at any of the sites sampled. Exact tests among the 324 possible pairwise comparisons demonstrated significant linkage disequilibrium $(\mathrm{p}<0.005)$ in only 5 cases (GA-3 to GA-5 in A, GA-2 to GA-5 in C, GA-3 to GA-4 in D, CT3 to CT-20 in E, and GA-1 to GA-4 in F). The global test across populations, for all 28 pairings of loci, was not significant in any case ( $p>0.006$; Bonferroni correction applied).

\section{Population substructure}

Pairwise population differentiation estimated by $\theta$ among all pairs of populations ranged from 0.00 to 0.095 (Table 2). The highest, and significantly different, $\theta$ values were between remote sites (A and $G_{;} \theta=$ 0.095, $\mathrm{p}<0.006$ ). Furthermore, these sites showed the highest and statistically significant values with respect to other sites (A to $F=0.093$ and $E$ to $G=0.057$; $p<$ 0.006). In contrast, the lowest and statistically similar values were found among the closest Sites B to F $(\theta=$ 
Table 2. Zostera marina. Matrix of pairwise comparisons of $\theta$ among 7 sites in SQB. A, West Head; B, West Arm; C, Monte Ceniza; D, Mouth; E, Pedregal; F, Molino Viejo; G, East Head. Values in bold are significantly different $(p<0.006$; Bonferroni correction)

\begin{tabular}{|lcccccc|}
\hline & $\mathrm{A}$ & $\mathrm{B}$ & $\mathrm{C}$ & $\mathrm{D}$ & $\mathrm{E}$ & $\mathrm{F}$ \\
\hline $\mathrm{B}$ & $\mathbf{0 . 0 6}$ & & & & & \\
$\mathrm{C}$ & $\mathbf{0 . 0 7}$ & 0.00 & & & & \\
$\mathrm{D}$ & $\mathbf{0 . 0 7}$ & 0.00 & 0.00 & & & \\
$\mathrm{E}$ & $\mathbf{0 . 0 9}$ & 0.00 & 0.01 & 0.01 & & \\
$\mathrm{~F}$ & $\mathbf{0 . 0 9}$ & 0.01 & 0.00 & 0.00 & 0.01 & \\
$\mathrm{G}$ & $\mathbf{0 . 1 0}$ & $\mathbf{0 . 0 4}$ & $\mathbf{0 . 0 4}$ & $\mathbf{0 . 0 3}$ & $\mathbf{0 . 0 6}$ & $\mathbf{0 . 0 5}$ \\
\hline
\end{tabular}

0.000 to $0.009 ; \mathrm{p}>0.006$ ) (Table 2). Among all subpopulations, a significant association between genetic $\left(\theta[\theta-1]^{-1}\right)$ and geographical $(\log \mathrm{km})$ distances $\left(\mathrm{r}^{2}=\right.$ $0.98 ; \mathrm{p}=0.015$; Fig. 2 ) was only found in the West Head subpopulation (A) relative to the other sampling sites.

The analysis of allelic frequencies $(\theta)$ suggested that the Zostera marina population in SQB contains 3 different genetic groups; however, the Bayesian clustering method suggested 4 different genetic groups ( $K=$ $4)$. The Ln probability of the data was minimum with $K=1(\mathrm{Ln}=-2760.2)$ and maximum with $K=4$ populations ( $\mathrm{Ln}=-2749.8$ ), thus suggesting that the pooled 'population' of $Z$. marina in SQB is heterogeneous and may contain 4 genetically distinct groups. Assignment analysis showed that most individuals $(q>0.95)$ were correctly assigned to each site from which they were sampled, suggesting that each original sampled site formed a distinct subpopulation.

\section{Migration}

The mouth of the coastal lagoon (Sites B, C and D) showed a mixed pattern of gene flow without a unidi-

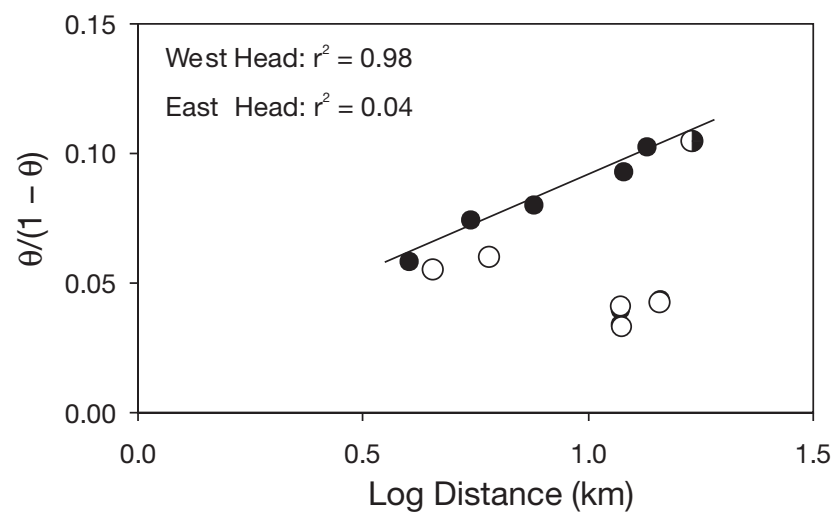

Fig. 2. Zostera marina. Relationships between estimated genetic distance $(\theta)$ and geographical distance $(\log \mathrm{km})$ among subpopulations relative to the West Head $(\bullet)$ and East Head (O) sites in SQB rectional pattern (Fig. 3). In contrast, there was a clear pattern of asymmetrical gene flow from the mouth towards the West Head (A). While there was no predominant gene flow between Sites G and F, there was a clear pattern of gene flow from the East Head (G) towards the mouth of the coastal lagoon (D).

\section{Bottleneck test}

No indication of a recent genetic bottleneck in the Zostera marina population was found at any of the sites within SQB. Under the assumptions of the 3 models of microsatellite mutation (IAM, SMM and TPM), none of the 7 sites showed a significant excess of heterozygosity $(p>0.006)$. While there was no significant heterozygosity excess, heterozygosity deficit was observed under the TPM for 3 sites (B, C, D) and the SMM for 2 sites $(B, D)(p<0.006$, Table 3$)$. In contrast, under the IAM, none of the subpopulations demonstrated significant heterozygosity deficiency ( $p>0.006)$.

\section{DISCUSSION}

\section{Genetic substructure}

This study showed that Zostera marina populations can be genetically structured in small and heterogeneous embayments such as SQB. Allelic frequencies ( $\theta$ ) suggested that the $Z$. marina population in SQB contains 3 different genetic groups, whereas Bayesian

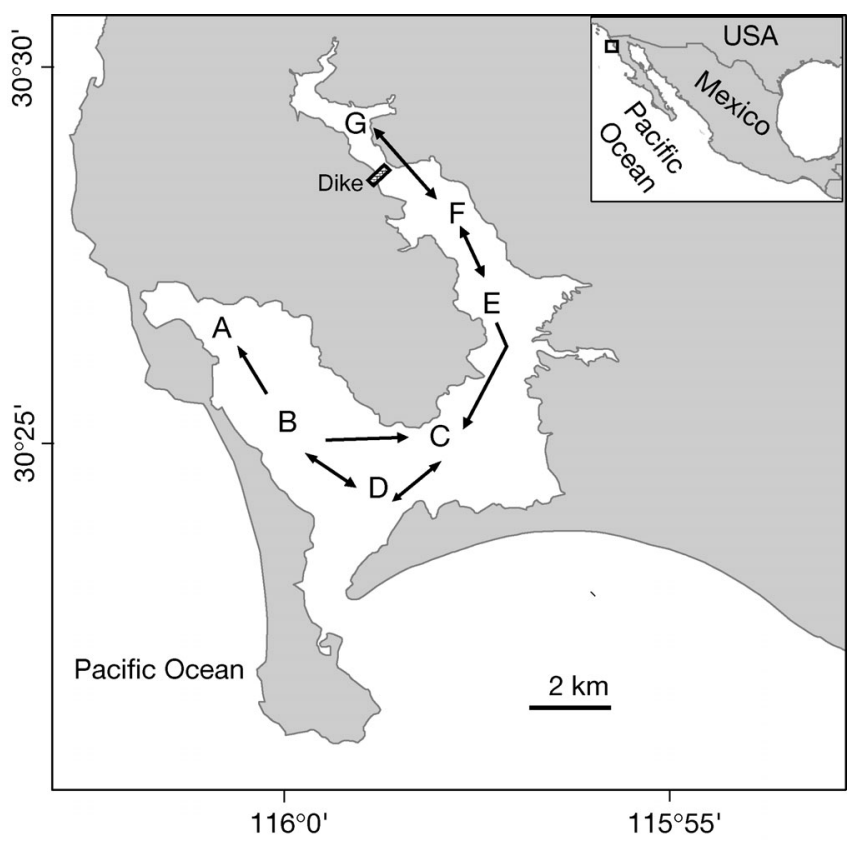

Fig. 3. Zostera marina. Polarity of gene flow among sites in SQB based on MIGRATE analysis 
Table 3. Zostera marina. Bottleneck test (heterozygosity deficiency test) in SQB. A, West Head; B, West Arm; C, Monte Ceniza; D, Mouth; E, Pedregal; F, Molino Viejo; G, East Head; SMM, stepwise mutation model; TPM, Two Phase model. Values in bold statistically significant $(p<0.006$; Bonferroni correction), variance 9.0 , probability $88 \%$

\begin{tabular}{|c|c|c|c|c|c|c|}
\hline \multirow[t]{3}{*}{ Site } & \multicolumn{3}{|c|}{ SMM } & \multicolumn{3}{|c|}{ - TPM } \\
\hline & \multicolumn{2}{|c|}{ Sign test } & \multirow{2}{*}{$\begin{array}{c}\text { Wilcoxon } \\
\text { test } \\
\text { (deficiency) }\end{array}$} & \multicolumn{2}{|c|}{ Sign test } & \multirow{2}{*}{$\begin{array}{c}\text { Wilcoxon } \\
\text { test } \\
\text { (deficiency) }\end{array}$} \\
\hline & $H_{\mathrm{D}} / H_{\mathrm{E}}$ & $\mathrm{p}$ & & $H_{\mathrm{D}} / H_{\mathrm{E}}$ & $\mathrm{p}$ & \\
\hline A & $7 / 1$ & 0.009 & 0.006 & $6 / 2$ & 0.05 & $4 \quad 0.020$ \\
\hline B & $8 / 0$ & 0.001 & 0.002 & $8 / 0$ & 0.00 & 10.002 \\
\hline $\mathrm{C}$ & $7 / 1$ & 0.011 & 0.004 & $7 / 1$ & 0.01 & $2 \quad \mathbf{0 . 0 0 4}$ \\
\hline D & $8 / 0$ & 0.001 & 0.002 & $8 / 0$ & 0.00 & 10.002 \\
\hline E & $7 / 1$ & 0.011 & 0.010 & $6 / 2$ & 0.06 & $2 \quad 0.020$ \\
\hline $\mathrm{F}$ & $7 / 1$ & 0.015 & 0.014 & $6 / 2$ & 0.07 & $7 \quad 0.020$ \\
\hline G & $7 / 1$ & 0.012 & 0.010 & $6 / 2$ & 0.06 & $5 \quad 0.020$ \\
\hline
\end{tabular}

clustering suggested that Z. marina in SQB is comprised of 4 genetically different groups. HardyWeinberg (HW) disequilibrium, due to significant excess of homozygotes, was observed when the 7 sites were pooled, supporting the hypothesis that the $Z$. marina population is genetically substructured in SQB. In addition, even when statistically non-differentiated B, C, D, E and F sites were pooled, they also showed HW disequilibrium due to significant excess of homozygotes. This further suggested that there is genetic substructuring among these sites, supporting the Bayesian analysis. Consequently, the $Z$. marina population at SQB is likely to have at least 4 different genetic groups. On the other hand, an excess of homozygotes in population samples might also be the result of null alleles, which could lead to a false observation of excess of homozygotes. However, null alleles at all loci per site in SQB were extremely rare $(<6 \%)$ and were not present at most of the loci.

The greatest and significant genetic difference among sites at SQB was observed between the most distant sites (A and $G_{\text {; }}$ separated by $22 \mathrm{~km}$ ). The West Head (A) is approximately $8 \mathrm{~km}$ away from the mouth of the bay, and water residence time here is approximately 5 d (Camacho-Ibar et al. 2003). The East Head (G) is approximately $14 \mathrm{~km}$ from the mouth, is the most isolated site, and water flow is restricted by a dike. Furthermore, water flow at the East Head is constrained within a channel approximately $10 \mathrm{~m}$ wide due to the construction of a dike. The geographic distance from the East Head to the mouth and the restricted water flow result in lower current rates $\left(<60 \mathrm{~cm} \mathrm{~s}^{-1}\right)$ and an increase in water residence time ( $>21 \mathrm{~d}$ ) at the East Head compared to other sites in the coastal lagoon (Camacho-Ibar et al. 2003).

Gene flow in Zostera marina occurs mainly via hydrophilic pollination and seed dispersal; however, pollen viability of $Z$. marina is less than $48 \mathrm{~h}$ (De Cock 1980), and pollen and seeds are negatively buoyant. Under these circumstances, pollen and seeds reach maximum distances of $15 \mathrm{~m}$, even when water velocity reaches $80 \mathrm{~cm} \mathrm{~s}^{-1}$ (Ackerman 1986, 1997). While drifting reproductive shoots that carry seeds have been identified as a factor that could potentially enhance gene flow (Harwell \& Orth 2002, Reusch 2002, MuñizSalazar et al. 2005), their dispersal is restricted by the velocity and direction of the marine currents. Vegetative shoots with attached roots and rhizomes have been observed floating at the water surface and could potentially disperse long distances. Nevertheless, there is little evidence that these vegetative shoots can successfully reestablish naturally (Ewanchuk \& Williams 1996); therefore, at present they can not be considered vectors that increase gene flow. Consequently, it is unlikely that pollen, seeds, or drifting reproductive shoots can be transported in sufficient numbers to promote genetic homogeneity between the most distant sites (East Head and West Head) in SQB.

In contrast to East and West Head, there were no significant genetic differences (in terms of allelic frequencies) among meadows at the sites closest to the mouth $(\mathrm{B}, \mathrm{C}$ and $\mathrm{D})$ or between sites in the East Arm (E and F). Water currents are stronger at all these sites than at the Heads, and the water residence time can be less than 2 d (mouth) or 5 d (East Arm) (Camacho-Ibar et al. 2003). Tidal currents can reach $100 \mathrm{~cm} \mathrm{~s}^{-1}$ in the region near the mouth, but decrease toward the inner East Arm $\left(60 \mathrm{~cm} \mathrm{~s}^{-1}\right)$ due to changes in topography and bathymetry (Ocampo-Torres 1980, Martori-Oxamendi 1989). Therefore, the lack of genetic differentiation among the sites from the mouth ( $B, C$ and $D)$ is likely enhanced by an effective gene flow as a consequence of high current velocities relative to the heads of the bay.

Gene flow counteracts differentiation among populations caused by genetic drift or selection. When the species has a more or less continuous distribution range, the balance between these antagonistic forces may result in clines that may be gradual or sharp, and isolation by distance (IBD) will be detected (Wright 1943). In this study, IBD analysis showed 2 opposite patterns of genetic differentiation regarding geographic distances between Zostera marina sites in SQB. In the first pattern, the significant correlation between genetic and geographic distances of all sites with respect to the West Head, and the signature of asymmetrical gene flow from the coalescence analysis, suggested IBD in Z. marina from SQB. Because of the high correlation between genetic and geographic distances of all sites relative to the West Head, it is likely that these sites are in equilibrium between a high level of gene flow and genetic drift. Hence, subpopulations of $Z$. marina have probably existed undisturbed at SQB 
for a long time, which is consistent with the conclusions derived from the bottleneck analysis (see below).

In the second pattern, all sites relative to the East Head showed no significant correlation between genetic and geographic distances; therefore, IBD was not present among these sites. Strong population differentiation does not always translate into IBD, especially in areas where gene flow and genetic drift are not in equilibrium (Bossart 1998, Whitlock 1999). Gene flow can be influenced by marine currents and/or discontinuities in the habitat, which can create barriers to gene flow and favor genetic differentiation. Recent studies on fishes and invertebrates with long-distance dispersal larvae indicate that planktonic larvae can be locally retained and can generate genetic structure at small scales (Colin et al. 2003, Cowen et al. 2003, Taylor \& Hellberg 2003). For the reef fish Elacatinus evelynae inhabiting the Caribbean Sea, island populations separated by $23 \mathrm{~km}$ showed a strong genetic differentiation despite evidence for long larval dispersal potential and the absence of a physical biogeographic barrier (Taylor \& Hellberg 2003). This suggests that marine populations can remain demographically closed for thousands of generations. Consequently, the lack of IBD suggested that drifting reproductive shoots of Zostera marina are locally retained at the mouth, or that they are not effective vectors for long distance dispersal in SQB.

Small isolated populations are subject to genetic drift, which will impact their evolutionary potential through fixation of deleterious mutations (Grosberg \& Cunningham 2001). Since the East Head is the smallest and most isolated site in SQB, the gene exchange with other sites will be restricted and will be under the strong influence of genetic drift, corroborating the lack of equilibrium between gene flow and genetic drift. Recent studies on IBD analysis of Zostera marina populations around the world have shown that genetic differences in relation to geographic distance are regionspecific. For example, the central Baltic and the Black Sea are characterized by populations with low clonal diversity and high population differentiation, but with opposite effects on IBD over similar spatial scales (Olsen et al. 2004). Likewise, IBD analysis showed a significant correlation between genetic and geographical distances in Gulf of California populations of Z. marina, but not in Pacific coast populations (MuñizSalazar et al. 2005). The lack of differentiation in the IBD slopes between the European populations and between the Mexican Z. marina populations reflects differences in dispersal patterns influenced by ocean currents (Olsen et al. 2004, Muñiz-Salazar et al. 2005). Consequently, our study showed that the small scale of IBD in populations of $Z$. marina may also be site specific, depending on local current regimes.
In the present study, the greatest genetic differentiation between sites $(\theta=0.10)$ was 6 -fold greater than between populations of Zostera marina in the Baltic Sea $(\theta=0.02$; Reusch 2002), and 3-fold greater than observed in the Gulf of California $(\theta=0.04$; MuñizSalazar et al. 2005). Interestingly, sites in SQB are only separated by $22 \mathrm{~km}$, in contrast to $54 \mathrm{~km}$ in the Baltic Sea and $250 \mathrm{~km}$ in the Gulf of California. Similarly to our study, Billingham (2003) found significant genetic differentiation $(\theta=0.23$ ) among $Z$. marina populations over short distances of 5 to $15 \mathrm{~km}$ in a coastal lagoon. $\mathrm{SQB}$ is a small but heterogeneous habitat characterized by clear nutrient, salinity, and temperature gradients from the mouth to the heads of the bay. Higher temperatures and salinities are found at the heads than at the mouth as a result of greater water residence times, lower current velocities, and shallower depths that promote heating and greater evaporation rates. These oceanographic characteristics promote barriers to the dispersion of propagules, such as pollen, seeds and reproductive shoots. Collectively, these results suggested that the restriction of water flow, the current pattern, and the distance between sites can reduce genetic flow and induce genetic differences in $Z$. marina at both small and large scales. Thus, we propose that genetic exchange occurs mainly among $Z$. marina individuals of the same sites at each head (A and G), among individuals from the B to D group, and among individuals from the $\mathrm{E}$ to $\mathrm{F}$ group.

\section{Bottleneck analysis}

Fragmentation and loss of seagrass habitat caused by natural and/or anthropogenic disturbances has led to a decrease in genetic diversity of seagrass populations in estuaries and coastal lagoons (Alberte et al. 1994, Ruckelshaus 1998, Williams \& Orth 1998, Williams 2001, Muñiz-Salazar et al. 2005). However, populations of Zostera marina from the Wadden SeaNorth Sea-Baltic region show high levels of genetic diversity (allelic richness $[\mathrm{AR}]=4.06$ to 4.10 ; Olsen et al. 2004), even though the meadow cover has been declining since 1930 as result of anthropogenic activities and wasting disease (Baden et al. 2003, Bostrom et al. 2003). Similarly, the heterozygosity excess test showed that the genetic diversity of $Z$. marina has not reduced at all sites in $\mathrm{SQB}$, even though the population is genetically structured and a $14 \%$ reduction of its cover has been reported (Ward et al. 2004a,b). Moreover, the levels of genetic diversity at all sites in SQB $(\mathrm{AR}=4.1$ to 5.4$)$ were similar to other perennial $Z$. marina populations where no disturbances have been documented. For example, pristine populations of $Z$. marina from the Pacific coast of Baja California show 
AR values ranging 3.7 to 6.1 (Muñiz-Salazar et al. 2005). Consequently, no recent bottleneck was identified in this study, suggesting that the 7 subpopulations of $Z$. marina in $\mathrm{SQB}$ are in mutation-drift equilibrium. Furthermore, it is important to point out that because the genetic structure of a population reflects historical events (Grosberg \& Cunningham 2001), the present decrease in cover of $Z$. marina meadows in SQB might not have been revealed yet in current levels of genetic diversity. Additionally, it is possible that a bottleneck was present but was too small to be detectable.

Though a bottleneck was not observed, significant heterozygosity deficit suggested a recent expansion in the population size, or a recent influx of rare alleles from genetically distinct immigrants (Luikart \& Cornuet 1998). In this study, 3 sites (B, C and D) showed significant heterozygosity deficit under TPM, and 2 sites (B and D) under SMM. Although there has been a general decrease in the cover of Zostera marina in $\mathrm{SQB}$, especially in the subtidal meadows, an expansion of the intertidal meadows close to the mouth has been observed since 1987 (Ward et al. 2004b). Consequently, a recent expansion of the population size at the mouth sites is likely. Even though the genetic flow between SQB and other populations of $Z$. marina along the Pacific coast is restricted (Muñiz-Salazar et al. 2005), genetic exchange will probably occur - primarily at sites closest to the mouth (B, C and D).

In this study, we found that different physical conditions within SQB are likely to be responsible for the genetic structure and diversity of Zostera marina in this small coastal lagoon. These results suggest that if genetic structure exists in $Z$. marina, it is likely that other species of marine plants or animals with similar dispersal or reproduction characteristics may experience genetic isolation. This further suggests that these organisms may also be genetically structured in small embayments with different water regimens. Further research of the clonal and genetic diversity of the $Z$. marina population is necessary to provide conclusive evidence of inbreeding and bottleneck events in SQB, which will have important implications for the conservation and management of this species.

Acknowledgements. We thank J. Rearick, I. Williams, B. Pierson, J. Pearce, Judy Gust (USGS/ASC) and N. Victoria-Cota (UABC) for their help in the laboratory. We also thank J. M. Guzmán, D. Mather and M. Anderson for their help during field sampling. This study was supported through grants funded by the Universidad Autonoma de Baja California (4033, 4023) and Ramsar Convention on Wetlands (WFF/002/MEX/3) to ACP and DHW. Other funds were provided by the U.S. Fish and Wildlife Service-North America Wetland Conservation Act, Ducks Unlimited of México (DUMAC), U.S. Geological Survey-Alaska Science Center and Exportadora de Sal, S.A.

\section{LITERATURE CITED}

Ackerman JD (1986) Mechanistic implications for pollination in the marine angiosperm Zostera marina. Aquat Bot 24: $343-353$

Ackerman JD (1997) Submarine pollination in the marine angiosperm Zostera marina (Zosteraceae). II. Pollen transport in flow fields and capture by stigmas. Am J Bot 84: $1110-1119$

Aguirre-Muñoz A, Buddemier RW, Camacho-Ibar VF, Carriquiry JD, Ibarra-Obando SE, Massey BW, Smith SV, Wulff F (2001) Sustainability of coastal resource use in San Quintin, México. Ambio 30:142-149

Alberte RS, Suba GK, Procaccini G, Zimmerman RC (1994) Assessment of genetic diversity of seagrass population using DNA fingerprinting: implications for population stability and management. Proc Natl Acad Sci USA 91:1049-1053

Álvarez-Borrego S (2004) Nutrient and phytoplankton dynamics in a coastal lagoon strongly affected by coastal upwelling. Cienc Mar 30:1-19

Avise JC (1994) Molecular markers, natural history and evolution. Chapman \& Hall, New York

Baden S, Gullstrom M, Lunden B, Pihl L, Rosenberg R (2003) Vanishing seagrass (Zostera marina, L.) in Swedish coastal waters. Ambio 32:374-377

Beerli P, Felsenstein J (1999) Maximum likelihood estimation of migration rates and effective population numbers in two populations using a coalescent approach. Genetics 152: 763-773

Billingham MR, Reusch THB, Alberto F, Serrao E (2003) Is asexual reproduction more important at geographical limits? A genetic study of the seagrass Zostera marina in the Rio Formosa, Portugal. Mar Ecol Prog Ser 265:77-83

Bilton DT, Paula J, Bishop DD (2002) Dispersal, genetic differentiation and speciation in estuarine organisms. Estuar Coast Shelf Sci 55:937-952

Bockelmann AC, Reusch TBH, Bijlsma K, Bakker JP (2003) Habitat differentiation vs isolation by distance: the genetic population structure of Elymus athericus in European saltmarshes. Mol Ecol 12:505-515

Bossart JL (1998) Genetic estimates of population structure and gene flow: limitations, lessons and new directions. Trends Ecol Evol 13:202-206

Bostrom C, Baden SP, Krause-Jensen D (2003) The seagrasses of Scandinavia and the Baltic Sea. In: Green EP, Short FT (eds) World atlas of seagrasses. University of California Press, Berkeley, p 35-45

Cabello-Pasini A, Muñiz-Salazar R, Ward DH (2003) Annual variations of biomass and photosynthesis in Zostera marina L. along the Pacific Coast of Baja California, Mexico. Aquat Bot 76:31-47

Cabello-Pasini A, Muñiz-Salazar R, Ward DH (2004) Biochemical characterization of the seagrass Zostera marina at its southern distribution limit in the North Pacific. Cienc Mar 30:21-34

Camacho-Ibar VF, Carriquiry JD, Smith SV (2003) Nonconservative $\mathrm{P}$ and $\mathrm{N}$ fluxes and net ecosystem production in San Quintin Bay, Mexico. Estuaries 26:1220-1237

Colin PL, Taylor MS, Hellberg ME, Warner RR, Palumbi SR (2003) Larvae retention: genes or oceanography? Science 300:1657-1659

Cornuet JM, Luikart G (1996) Description and power analysis of two tests for detecting recent population bottlenecks from allele frequency data. Genetics 144:2001-2014

Correa F, Collins E, Oceguera A, Cordero B, Domínguez D (2004) Allozymic variation in the Pacific oyster Crassostrea gigas from San Quintin Bay, Baja California, Mexico. 
Cienc Mar 30:89-97

Cowen RK, Paris CB, Olson DB, Fortuna JL (2003) The role of long distance dispersal versus local retention in replenishing marine populations. Gulf Caribb Res 14:129-137

De Cock A (1980) Flowering, pollination and fruiting in Zostera marina L. Aquat Bot 9:201-220

Di Rienzo A, Peterson AC, Garza JC, Valdes AM, Slatkin M, Freimer NB (1994) Mutational processes of simplesequence repeat loci in human populations. Proc Natl Acad Sci USA 91:3166-3170

Ewanchuk PJ, Williams SL (1996) Survival and re-establishment of vegetative fragmentation of eelgrass (Zostera marina L.). Can J Bot 74:1584-1590

Garcí-Esquivel S, González-Gómez MA, Ley-Lou F, MejíaTrejo A. (2004) Oyster culture potential in the west arm of San Quintín Bay: current biomass and preliminary estimate of the carrying capacity. Cienc Mar 30:61-74

Garza JC, Williamson EG (2001) Detection of reduction in population size using data from microsatellite loci. Mol Ecol 10:305-318

Grosberg R, Cunningham CW (2001) Genetic structure in the sea. From populations to communities. In: Bertness $M$, Gaines SD, Hay ME (eds) Marine community ecology. Sinauer Associates, Sunderland MA, p 61-84

Guo SW, Thompson EA (1992) Performing the exact test of Hardy-Weinberg proportion for multiple alleles. Biometrics $48: 361-372$

Harwell MC, Orth RJ (2002) Long-distance dispersal potential in marine macrophytes. Ecology 83:3319-3330

Hedgecock D (1986) Is gene flow from pelagic larval dispersal important in the adaptation and evolution of marine invertebrates? Bull Mar Sci 39:550-564

Hernández-Ayon JM, Galindo Bect S, Camacho-Ibar V, García-Esquivel S, González-Gómez MA, Ley-Lou F (2004) Nutrient dynamics in the west arm of San Quintín Bay, Baja California, Mexico. Cienc Mar 30:119-132

Kimura M, Crow JF (1964) The number of alleles that can be maintained in a finite populations. Genetics 49:725-738

Kusumo HT, Druehl LD (2000) Variability over space and time in the genetic structure of the winged kelp Alaria marginata. Mar Biol 136:397-409

Luikart G, Cornuet JM (1998) Empirical evaluation of a test for identifying recently bottlenecked populations from allele frequency data. Conserv Biol 12:228-237

Luikart G, Sherwin B, Steele BM, Allendorf FW (1998a) Usefulness of molecular markers for detecting population bottlenecks via monitoring genetic change. Mol Ecol 7: 963-974

Luikart G, Allendorf FW, Cornuet JM, Sherwin WB (1998b) Distortion of allele frequency distributions provides a test for recent population bottlenecks. J Hered 89:238-247

Martori-Oxamendi JI (1989) Variabilidad de la circulación y sus causas en Bahía San Quintín, B.C. MS thesis, CICESE, Ensenada

Meling-López AE (2001) Estrategias adaptativas de Zostera marina L. en el noroeste de Mexico: contraste entre ambientes. PhD thesis, CICESE, Ensenada

Muñiz-Salazar R, Talbot SL, Sage GK, Ward DH, CabelloPasini A (2005) Population genetic structure of annual and perennial populations of Zostera marina L. along the Pacific coast of Baja California and the Gulf of California. Mol Ecol 14:711-722

Nei M (1987) Molecular evolutionary genetics. Columbia University Press, New York

Neigel JE, Avise JC (1986) Phylogenetic relationships of mitochondrial DNA under various demographic models of speciation. In: Karlin S, Nevo E (eds) Evolutionary process and theory. Academic Press, New York, p 515-534

Ocampo-Torres FJ (1980) Análisis de mareas y predicción de velocidad mediante un modelo unidimensional en Bahía San Quintín, BC. MSc thesis, Universidad Autónoma de Baja California, Ensenada

Ohta J, Kimura M (1973) A model of mutation appropriate to estimate the number of electrophoretically detectable alleles in a finite populations. Genet Res 22:201-204

Olsen JL, Stam WT, Coyer JA, Reusch TBH and 14 others (2004) North Atlantic phylogeography and large-scale population differentiation of the seagrass Zostera marina L. Mol Ecol 13:1923-1941

Orth RJ, Luckenbach M, Moore KA (1994) Seed dispersal in a marine macrophyte: implications for colonization and restoration. Ecology 75:1927-1939

Pielou EC (1969) An introduction to mathematical ecology. Wiley Interscience, New York

Piry S, Luikart G, Cornuet JM (1997) BOTTLENECK: a program for detecting recent effective population size reductions from allele frequency data. J Hered 86:248-249

Poumián-Tapia M, Ibarra-Obando SE (1999) Demography and biomass of the seagrass Zostera marina in a Mexican coastal lagoon. Estuaries 22:879-889

Pritchard JK, Stephens M, Donnelly P (2000) Inference of population structure using multilocus genotype data. Genetics 155:945-959

Procaccini G, Mazella L (1998) Population genetic structure and gene flow in the seagrass Posidonia oceanica assessed using microsatellite analysis. Mar Ecol Prog Ser 169: 133-141

Procaccini G, Acunto S, Fama P, Maltagliati F (1999) Structural, morphological and genetic variability in Halophila stipulacea (Hydrocharitaceae) populations in the western Mediterranean. Mar Biol 135:181-189

Raymond M, Rousset F (1995) GENEPOP (v.1.2): population genetics software for exact test and ecumenicism. J Hered 86:248-249

Reusch TBH (2000) Five microsatellite loci in eelgrass Zostera marina and a test of cross-species amplification in $Z$. noltii and Z. japonica. Mol Ecol 9:365-378

Reusch TBH (2002) Microsatellites reveal high population connectivity in eelgrass (Zostera marina) in two contrasting coastal areas. Limnol Oceanogr 47:78-85

Reusch TBH, Stam WT, Olsen JL (1999) Microsatellite loci in eelgrass Zostera marina reveal marked polymorphism within and among populations. Mol Ecol 8:317-321

Rice WR (1989) Analyzing tables of statistical tests. Evolution 43:223-225

Rousset F (1997) Genetic differentiation and estimation of gene flow from F-statistics under isolation by distance. Genetics 145:1219-1228

Ruckelshaus MH (1998) Spatial scale of genetic structure and an indirect estimate of gene flow in eelgrass, Zostera marina. Evolution 52:330-343

Ruggiero MV, Reusch TBH, Procaccini G (2005) Local genetic structure in a clonal dioecious angiosperm. Mol Ecol 14: 957-967

Simpson EH (1949) Measurement of diversity. Nature 163: 688-692

Slatkin M (1987) Gene flow and the geographic structure of natural populations. Science 236:787-792

Taylor MS, Hellberg ME (2003) Genetic evidence for local retention of pelagic larvae in a Caribbean reef fish. Science 299:107-109

Valieré N (2002) GIMLET: a computer program for analyzing genetic individual identification data. Mol Ecol Notes 2: $377-379$ 
Ward DH, Morton A, Tibbitts LT, Douglas DC, CarreraGonzález E (2004a) Long-term change in eelgrass distribution at Bahía San Quintín, Baja California, Mexico, using satellite imagery. Estuaries 26:1529-1539

Ward DH, Tibbitts LT, Morton A, Carrera-González E, Kempka R (2004b) Use of digital multispectral videography to assess seagrass distribution in San Quintin Bay, Baja California, México. Cienc Mar 30:57-70

Weir BS, Cockerham CC (1984) Estimating F-statistics for the analysis of population structure. Evolution 38:1358-1370

Whitlock MC (1999) Indirect measures of gene flow and migration. Heredity 82:117-125

Williams SL (2001) Reduced genetic diversity in eelgrass

Editorial responsibility: Otto Kinne (Editor-in-Chief),

Oldendorf/Luhe, Germany transplantations affects both population growth and individual fitness. Ecol Appl 11:1472-1488

Williams SL, Orth RJ (1998) Genetic diversity and structure of natural and transplanted eelgrass populations in the Chesapeake and Chincoteague Bays. Estuaries 21: 118-128

Wright S (1943) Isolation by distance. Genetics 28:114-138

Young AG, Clarke GM (2000) Conclusions and future directions: what do we know about the genetic and demographic effects of habitat fragmentation and where do we go from here? In: Young AG, Clarke GM (eds) Genetics, demography and viability of fragmented populations. Cambridge University Press, Cambridge, p 361-366

Submitted: February 4, 2005; Accepted: September 19, 2005 Proofs received from author(s): February 8, 2006 